\title{
A Comparative Study of Novel Translation under Feminist Translation Theory: A Case Study of the Two Chinese Versions of To the Lighthouse*
}

\author{
Qing Qiu \\ School of Intercultural Studies, Jiangxi Normal University, Nanchang, China
}

\begin{abstract}
With the increasing relevance of feminism and translation studies, how to embody female discourse in translation has become an important issue in feminist translation and in reflecting the translator's subjectivity. Based on the feminist translation theory, this study will explore how female translators use translation strategies and methods to highlight female discourse through a comparative analysis of the two Chinese versions of To the Lighthouse, aiming to reveal the differences between female's translation and male's as a result of their gender consciousness, thus bringing beneficial inspiration to translation studies and translation work.
\end{abstract}

Index Terms - feminist translation theory, female discourse, To the Lighthouse

\section{INTRODUCTION}

To the Lighthouse is a well-known novel by British woman writer Virginia Woolf published in 1927, a masterpiece withstanding the test of time in literary circle. Since its publication, there has been unceasing studies on it, some commenting on the classic from linguistic and literary perspectives, some discussing it in terms of the spirit conveyed by the novel itself or the plot in the book, and a few analyzing it from the perspective of translation. This paper will make a comparative study of the two Chinese versions of To the Lighthouse from the perspective of translation on the base of feminist translation theory. The research of feminist translation theory in academic circles has been putting focus on the theory itself, the research on female translators' translation works being scarce. Therefore, this comparative study of a male translation version and a female version will somewhat make up the vacancy in the research field.

\section{LITERATURE REVIEW}

Feminist translation theory originated from free feminism in the 18th century and flourished in the 1960s and 1970s, arising from the translation practice of Canadian feminists. The most famous representatives are Lori Chamberlain, Barbara Godard, Spivak Gayatri Chakravorty, Sherry Simon and Louise von Flotow. Lori published her thesis Gender and the Metaphorics of Translation in 1988. What she proposes in the thesis is to examine what is at stake for gender in the representation of translation: the struggle for authority and the politics of originality informing this struggle. Barbara (1990) believes that as an emancipatory practice, feminist discourse is a political discourse directed towards the construction of new meanings and is focused on subjects becoming in/by language. Spivak (1993), an Indian-American scholar, agrees that it is not bodies of meaning that are transferred in translation. The task of the feminist translator is to consider language as a clue to the workings of gendered agency. The writer is written by her language. But the writing of the writer writes agency in a way that might be different from that of the British woman/citizen within the history of British feminism, focused on the task of feeling herself from Britain's imperial past, its often racist present, as well as its "made in Britain" history of male domination. Gender in Translation written by Sherry Simon in 1996 is the first comprehensive study of feminist issues in translations theory and practice. Sherry Simon shows how women translators have long acted as literary activists, creating new lines of transmission and contributing to cultural debates. Contemporary feminist translators have had decisive influence in areas such as French feminism and Bible translation. In investigating the role of gender in translation, Sherry Simon shows how translation studies can be enriched by a cultural studies framework. In Flotow's work Translation and Gender, published in 1997, she examines the influences that feminist thought and writing have had on contemporary translation practice, presents theoretical developments and critical work on translation, discusses some of the criticisms addressed to work that combines gender issues with translation studies, and offers some remarks on future perspectives and a concluding statement, respectively.

Feminist translation theory was introduced to China by Professor Zhu Hong in the 1980s, but it was not until 2000 that it gradually attracted the attention of the academic circles. At the beginning, the study of feminist translation theory in academic circles mainly focused on the introduction of the theory and preliminary exploration of feminist translation

\footnotetext{
${ }^{*}$ Sponsored by Multimodal Interaction Research in Foreign Language Teaching, a Social Science Project of Jiangxi (17YY04).
} 
thought: Liao Qiyi (2002) shares that although feminist translation had some defects, it recognizes that specific cultural and political factors will have an impact on people's views and their translation process; Ge Xiaoqin (2003) points out that translation involves the collision and fusion between different cultures, the process of which is very complicated, and feminist translation theory is to intervene in the culture involved in the process through a series of means and rewrite the dialogue at the same time; Liu Junping (2004) has made a thorough analysis of the relationship among translation, women, authors, texts, translators and readers; Xu Lai (2004) has criticized the phenomenon of discrimination against female translators on the basis of the theory from Simon and Flotow, playing a vital role in striving for the dignity and equality of female translators. In a word, feminist translation theory, on the one hand, advocates that translation is a re-creation based on the original work. On the other hand, it emphasizes the influence of translator's gender consciousness on translation. From 2005 to 2007, scholars began to research feminist translation theory combined with feminist translation work. The most representative ones are Chen Yu and Chen Lin's Feminist Rewriting of the Discourses - With a comparative Study on the Two Translation Versions of Jane Eyre and Yang Xue's Translators' Feminist Consciousness and the English Translating of Zang Hua Ci.

\section{A Comparative TeXtual Analysis of the Translations}

There are many Chinese translation versions of To the Lighthouse. Among them, the most representative are Ma Ainong's and Qu Shijing's. The former being a female translator and the latter a male one, the former published by People's Publishing House in 2013 and the latter by Shanghai Translation Publishing House in 2008, both of their versions are remarkable in the accuracy of the comprehension of the original and smooth in the re-expression. The comparative study is to be conducted in the following aspects:

\section{A. The Image of Characters}

In the process of translating a novel, the language used by the translator has an invisible effect on the image of the characters depicted. Different diction will leave a different impression of the characters in the readers' mind. Generally speaking, when describing female characters, female translators are more biased than male translators, while when describing male characters, the opposite is true. It's easier for women in female translators' works to leave a more positive impression that they are independent, strong and cute, and men a more negative impression that they are rude, irritable and arrogant.

\section{Example 1:}

The Original: “Aren't you drenched to the skin?” She had said.

Ma's Version: “你是不是浑身湿透了? ”她问。

Qu's Version: “您的衣服都湿透了吧？”她问道。

Analysis: It is a sentence said by Mrs. Ramsay when she cheats her guest atheist Charles Stanley. The addressor and the addressee enjoyed equal social status. The only difference between them is that Charles Stanley is a man and Mrs. Ramsay a woman. Mr. Qu chooses the word “您” when he translates “you”, a term to show respect to the addressed, as to a senior or a superior. The use of “您” implies that Mrs. Ramsay's status is lower than that of Charles Stanley. It makes people feel that Mrs. Ramsay is very menial and careful when she faces Charles Stanley. Gender inequality is a very common social phenomenon. Language is the "mirror" and "window" of society and the carrier of culture. Therefore, the inequality between men and women in society is inevitably reflected in language (He Xianbin, 2003). The word “您” portrays a submissive female image. However, Ma’s translation of “you” puts Mrs. Ramsay and Charles Stanley on an equal social stratification, indicating a woman's consciousness of gender equality. From this example, it can be seen that gender inequality is reflected more obviously in male translators' translation versions.

\section{Example 2:}

The Original: She was wild and fierce.

Ma's Version：她任性又乘戻。

Qu's Version：她任性得可怕。

Analysis: This example is a description of Cam's character, who is Ramsay's youngest daughter. It means that Cam is a very self-willed child. Although both Ma and Qu express in their translation that Cam is wayward, yet the intensity of feeling is different. Qu Shijing uses the word “可怕”, which means “terrible” to describe her willfulness. Vocabulary, like fossils, embodies the ideology and knowledge of people who coined and used them in the society (Liu Jianda, 1998). This word “可怕” implies Qu's disgust with the youngest daughter Cam. In contrast, Ma Ainong, a woman translator, does not demonstrate the same feeling towards the girl portraited by the original author, leaving the reader the impression that Cam is just a self-willed child as most children are and will not arouse dislike towards her. Thus, when describing the shortcomings of female characters, female translators tend to be more tolerant by using milder or more subjective terms than male translators.

\section{B. Linguistic Level}

Gender factors affect people's language behavior in a specific way. Women pay more attention to the accuracy, elegance, implicitness and euphemism of language in terms of pronunciation, vocabulary and grammar. At the same 
time, the application of hyperbole modifiers and the change of intonation show that there are more emotional factors in women's language. The influence of this gender factor is also reflected in translation. Compared with male translators, female translators prefer to exclamatory sentences and rhetorical questions, sentence final particles, reduplicated words as well as degree adverbs to express their views and feelings.

Example 3:

The Original: "ES, OF COURSE, if it's fine tomorrow," said Mrs. Ramsay.

Ma's Version: “行啊, 如果明天天气好, 当然没有问题, ”拉姆齐夫人说。

Qu's Version: “好, 要是明儿天晴, 准让你去, ”拉姆齐夫人说。

Analysis: For the translation of “ES”, Ma's version is “行啊” and Qu's version is “好”. The main difference between the two translations is that Ma adds a sentence final particle “啊” at the end of the sentence, which makes the speaker's tone more relaxed and pleasant, while Qu's translation is just one word “好” without any emotion, which makes the speaker's speech a bit rigid. Mrs. Ramsay is a gentle and lively person, so Ma's translation is more in line with Mrs. Ramsay's design than Qu's. In China, women prefer to use sentence final particles than men. Adding sentence final particles makes the speech more agreeable, amicable and pleasant. In English, the atmosphere of speech is often conveyed through the speaker's pronunciation, intonation or context. When translating these words, Chinese female translators are inclined to conveying the atmosphere of their speech to the readers by adding some sentence final particles.

Example 4:

The Original: Who must be bored to death sitting all day with nothing to do but polish the lamp and trim the wick and rake about on their scrap of garden, something to amuse them.

Ma's Version: 他们整天坐在那里擦擦灯盏, 剪剪灯芯, 在那个巴掌大的园子里耙耙泥土, 别的什么事也没有, 肯定闷得要死。

Qu's Version: 他们一定烦闷极了, 除了擦拭灯罩, 修剪灯芯, 整理他们那块地聊以娱乐外, 整天就坐在那儿, 没事可做。

Analysis: This part describes the state that the poor people have nothing to do. There are three verbs in the original text: "polish", "trim", "rake". When translating these three verbs, the main difference in Qu's and Ma's translation is that Ma uses reduplicated words. By using these reduplicated words, the poor people's action is slowed down and their leisurely tempo of life is duly illustrated. The readers will feel that the poor people are idle and their life boring. These reduplicated words make the article more expressive. Reduplicated words are especially popular with women in China, because they sound relaxing, leisurely and comfortable. Accordingly, in translation, female translators prefer to use reduplicated words more frequently to re-present the feelings in the original text.

Example 5:

The Original: Yes, he did say disagreeable things, Mrs. Ramsay admitted.

Ma's Version：是的，他的话听着不太顺耳，拉姆齐夫人承认。

Qu's Version：是的，他老是说些不中听的话，拉姆齐夫人想到。

Analysis: Ma Yinglong's translation of "he did say disagreeable things" in the original text is more euphemistic than that of Qu Shijing's. She adds a degree adverb “太” in the middle of “不顺耳”, which lends some courtesy to the speech and makes the reader feel more comfortable. By contrast, Mr. Qu translates “disagreeable” directly into “不中听”, a negative term, and combined with “老是”, an adverb of frequency preceding it, creating a much harsher discourse with a stronger sense of criticism. Gender factors affect people's language behavior in a specific way. Women pay more attention to the accuracy of voice, vocabulary and grammar, as well as the elegance, implicitness and euphemism of language (Qian Jin, 2004).

\section{Example 6:}

The Original: For Pure would have beauty, he thought, how could she help it?

Ma's Version：普鲁会出落得很美, 他想, 她怎么能不美呢?

Qu's Version：普鲁将会有美丽的姿容，他想，她没法长得不美。

Analysis: "How could she help it?" is a general interrogative sentence. When translating this general interrogative sentence, Ma Ailong uses hyperbole modifier-rhetorical sentence. The application of hyperbole modifiers and the change of intonation also show that there are more emotional factors in women's language (Qian Jin, 2004). Qu Shijing uses a declarative sentence. Although the meaning of this rhetorical sentence is the same as that of the declarative sentence, the intensity of the emotion is quite different. The tone of the rhetorical sentence is obviously stronger than that of the declarative one, which will impress the reader more deeply. Lakoff (1975) believes that women prefer exclamation and interrogative sentences, especially rhetorical sentence, in order to gain the recognition of listeners. In translation, female translators are also more likely to use rhetorical sentence and exclamations than male translators.

\section{The Use of Translation Strategies}

Feminist translators try to highlight the sexism of the original work or the source language with creative translation or even rewriting, thus arousing readers' thinking on gender issues. They have summed up many innovative feminist 
translation strategies and methods in a large number of rich translation practices, the most important of which is supplementing, prefacing and footnoting, and hijacking. In Ma Ainong's translation of To the Lighthouse, she makes frequent use of two feminist translation strategies: supplementing and hijacking.

\section{Example 7:}

The Original: She asked, addressing herself particularly to her daughters.

Ma's Version：她问。她对她的女儿们这样细致地解释着。

Qu's Version：她特别向她女儿们这样提出问题。

Analysis: In this example, Ma Ailong uses the feminist translation strategy of hijacking when she translates the word “particularly” as “细致地” in this example, while Qu directly translates the word “particularly” as “特别” without any re-creation. The term of Hijacking is recuperated by commentators and translators to describe the process by which a feminist translator applies 'corrective measures' to the work in hand, appropriating the text in order to construct feminist meaning. Hijacking graphically expresses and acknowledges the struggle for the control of meaning (Flotow, 1997). By using the translation strategy of hijacking, Ma's translation vividly embodies Mrs. Ramsay's patience and wisdom when she educates her children, which makes the image of Mrs. Ramsay intellectual and attracts more attention and interest from the readers to Mrs. Ramsay and her children. Translation thus becomes a political activity that has the objective of making women visible and resident in language and society (Flotow, 1997).

\section{Example 8:}

The Original: For they might go to the Lighthouse after all, and she must see if the stocking did not need to be an inch or two longer in the leg.

Ma's Version: 因为他们终归是要去灯塔的, 她得弄清长袜的腿部是否还要加长一两寸。

Qu's Version: 因为, 也许他们明天会到灯塔去, 她必须看一看那袜筒是否还需要加长一两寸。

Analysis: For the word "might" in the original text, Ma Ainong's translation and Qu Shijing's translation are totally different. The word "might" appears as a modal verb in this sentence. When it is used as a modal verb, it shows something is or was possible. When Qu Shijing translates the word, he uses literal translation and translates it into “也 许”. But Ma Ainong adopts the feminist translation strategy of "hijacking", changing the meaning of the word "might" and translates it into “终归”, which means that something is bound to happen. Ma Ainong, like Mrs. Ramsay, is a woman with more delicate mind, so she can more accurately capture Mrs. Ramsay's inner activities at this time than the male translator. She applies the word “终归” to vividly express Mrs. Ramsay’s inner thought: Mrs. Ramsay always firmly believes that they will go to the Lighthouse. This is bound to happen.

\section{Example 9:}

The Original: For had she not in her veins the blood of that very noble, if slightly mythical, Italian house, whose daughters, scattered about English drawing-rooms in the nineteenth century, had lisped so charmingly, and had stormed so wildly.

Ma's Version: 因为她的血管里不是也流淌着那个带有神话色彩的意大利贵族的血液？十九世纪，意大利名门 望族的女儿们分散在英国许多家庭的客厅里，妩媚动人，谈吐优雅，嬉笑怒骂，风情万种。

Qu's Version: 因为, 在她的血管中, 不是奔流着那带有神话色彩的意大利名门望族的高贵血液吗? 意大利的 大家闺秀们, 在十九世纪分散到英国各地家庭的客厅里, 她们谈吐风雅, 热情奔放, 令人倾倒。

Analysis: When translating this part of content, Ma Ailong uses the feminist translation strategy-supplement. Supplementing is a means of compensation, which is often used by translators. That is, by dealing with the word games in the original text, to supplement their own points of view. Ma Ainong adds “妩媚动人” and “风情万种”, two Chinese four-character structures, to describe the Italian ladies. These two phrases are used to describe women's good looks and charm. By adding them to the translation, Ma further enhances the image of the Italian ladies and projects a more attractive image of them to the readers, aiming to make the feminine visible in language so that women are seen and heard in the world (Sherry Simon, 1996).

\section{Example 10:}

The Original: Never did anybody look so sad. Bitter and black, half-way down, in the darkness, in the shaft which ran from the sunlight to the depths, perhaps a tear formed.

Ma's Version: 从来没有人显得这么沮丧。苦涩, 郁闷, 简直心灰意冷, 在黑暗中, 在从阳光落进深渊的幽深 井道里, 也许有一颗泪珠正在形成。

Qu's Version: 从来没人看上去显得如此沮丧, 愁苦而阴郁, 在黑暗之中, 在从地面的阳光通向地底的深渊的 坚井里下坠的途中, 也许一滴泪珠涌上了眼角。

Analysis: This example is a description of Marie, a Swiss girl who lives in Mrs. Ramsay's house. Marie's father has cancer of the throat. He lives in Switzerland, separated from Marie. His death will leave Marie a helpless orphan. At this thought, Mrs. Ramsay bears a special sympathy for Marie. In Mrs. Ramsay's view, Marie is very depressed and sad at this time. When translating the words "bitter" and "black" in the original text, Qu Shijing uses the words “愁苦” and “阴郁”, while Ma Ainong first uses the words “苦涩” and “郁闷”. But after that, she adopts the feminist translation strategy of “supplementing”, adding a new word “心灰意冷” to the translation. Female translators are more likely to 
have emotional resonance with the female characters in the novel. “心灰意冷” means someone is frustrated and depressed. In translating this sentence, Ma Ainong clearly conveys to the readers the sadness and despair of Marie's heart for her father's impending death from laryngeal cancer by adding the word “心灰意冷”.

\section{CONCLUSION}

Through a comparative study of Ma's and Qu's translation versions of To the Lighthouse, conclusion is reached that, in contrast with male translators, female translators pay more attention to the equality of men's and women's identities in portraying the images of characters and are more tolerant in describing the shortcomings of female characters; female translators are more sensitive than male translators in perceiving various behaviors and psychology of characters, and prefer to use rhetorical questions, sentence final particles and reduplicated words in translation when presenting the personality of the characters in the novel and conveying the context of the novel to the readers accurately; in order to embody their female translators' identity through the translated text and project a prominent image of the female, women translators will use various translation strategies when translating, such as supplement, hijacking and so on.

\section{REFERENCES}

[1] Barbara Godard. (1990). Theorizing Feminist Discourse/Translation. In Susan Bassnett and Andre Lefevere(Ed.), Translation and Culture. London: Frances Printer, 87-96.

[2] Chen Yu \& Chen Lin. (2005). Feminist Rewriting of the Discourses - With a Comparative Study on the Two Translation Versions of Jane Eyre. Journal of Shanxi Teachers University, 6, 120-123.

[3] He Xianbin. (2003). A Brief Analysis of Gender Issues in Translation Discourse. Foreign Languages and Their Teaching, 10, 40-42.

[4] Hu Zuoyou, Hu Xiaojuan \& Li Erwen. (2013). Reception of Feminist Translation Theory in China. Academics, 3, 152-160.

[5] Ge Xiaoqin. (2003). The Essence of Feminist Translation. Foreign Languages Research, 6, 35-38.

[6] Lori Chamberlain. (1988). Gender and the Metaphorics of Translation. The University of Chicago Press Journals, 13, 454-472.

[7] Liu Jianda. (1998). Sex Discrimination and Liberation in Language. Journal of Shandong Foreign Language Teaching, 1, 8-25.

[8] Liu Junping. (2004). Towards An East-West Discourse on Feminist Translation Studies. Chinese Translators Journal, 4, 3-6.

[9] Liao Qiyi. (2002). Re-write the Myths: Feminism and Translation Studies. Journal of Sichuan International Studies University, $18,106-109$.

[10] Louise von Flotow. (1997). Translation and Gender: Translating in the Era of Feminism. Manchester: St. Jerome Publishing.

[11] Ma Ainong. (2013). To the Lighthouse. Beijing: People's Publishing House.

[12] Qian Jin. (2004). A Survey of Gender Differences in Language. Literature Studies, 6, 47-50.

[13] Qu Shijing. (2008). To the Lighthouse. Shanghai: Shanghai Translation Publishing House.

[14] Robin Tolmach Lakoff. (1975). Language and Women's Place. New York: Harper \& Row.

[15] Spivak, Gayatri Chakravorty. (1993). The Politics of Translation. Spivak, Gayatri Chakravorty(Ed.), Outside in the Teaching Machine. New York: Routledge, 179-200.

[16] Sherry Simon. (1996). Gender in Translation: Cultural Identity and the Politics of Translation. New York: Routledge.

[17] Woolf Virginia. (2013). To the Lighthouse. Beijing: Central Compilation and Publishing House.

[18] Xu Lai. (2004). "Rewriting" in the Name of Feminine-The Significance of the Feminism Translation Theory in the Study of the Translator's Subjectivity. Chinese Translators Journal, 4, 16-19.

[19] Yang Xue. (2007). Translators' Feminist Consciousness and the English Translating of Zang Hua Ci. Journal of Shanghai University, 1, 125-130.

Qing Qiu holds a PhD degree in English Language \& Literature from Sun Yat-sen University in 2016. She is now a Lecturer in the School of Intercultural Studies at Jiangxi Normal University. Her research interests include Systemic Functional Linguistics, Translation Studies and Multimodal Discourse Analysis. 